\title{
Reinhart Fuchs.
}

Herausgegeben

von

Karl Reissenberger.

Zweite Auflage.

Halle a. S.

Max Niemeyer.

1908. 
